\title{
Instruments for financing housing construction in the United States in the context of globalization
}

\author{
Mariia Ermilova ${ }^{1, *}$, Natalya Gryzunova ${ }^{1}$ \\ ${ }^{1}$ Plekhanov Russian University of Economics, Department of Financial Management, Stremyanny \\ lane, 36, 117997, Moscow, Russia
}

\begin{abstract}
.
Research background: The housing and construction markets are one of the main segments of the economy of any country. Solving several social and economic problems of the state, it is required to ensure the efficient operation of these markets. The leading economy in the world is the US economy. The tools and mechanisms used in the American market have been adapted in other countries as well. The main questions facing market participants are securing funding. Moreover, financing should be so efficiently established that the maximum number of entities will be able to use it to implement their tasks.

Purpose of the article: Within the framework of this study, a list of instruments for financing the construction of residential real estate was identified, which can be successfully adapted in the Russian economy in the context of globalization and taking into account the consequences that occur as a result of various crises.

Methods: The research used methods of analysis and synthesis, statistical analysis, modeling, logical analogy and generalization of results.

Findings \& Value added: The results of the study showed that the American system of financing the construction of residential real estate is differentiated. The subject composition of markets allows us to solve every problem that appears in the process of functioning of the markets. The insurance system is well-functioning. The presence of a system of guarantees further protects the rights of market participants. Thus, analyzing the possibilities of adapting the American experience in Russian practice, it was determined that the development of the mortgage segment and the introduction of a guarantee system would be effective.
\end{abstract}

Keywords: globalization; housing market; construction market; housing construction credit; mortgage

JEL Classification: $R 30$; $G 15 ; F 65$

\footnotetext{
* Corresponding author: masha080487@mail.ru
} 


\section{Introduction and literature review}

The housing problem is relevant for most countries and the United States is no exception. Being the leading economy of the world, one way or another, the housing market is faced with the fact that it is necessary to formulate financing instruments that will ensure the effective construction of housing market facilities. This determines the relevance of the study. It should be noted that modern US housing and construction markets are among the most developed in the world, both in terms of functioning and financing.

The classic types of residential real estate are apartments and houses. The main instrument for financing the construction of housing market facilities are mortgage loans. Mortgage lending developed quite rapidly in the United States until the global financial crisis, which began in 2007. In addition, indicators of volumes of mortgage lending by now have recovered quite quickly. Already in 2016, the volume of the mortgage market amounted to $77 \%$ of the country's GDP. This indicator is lower than in the pre-crisis period. However, this was explained by the fact that the economic system has not yet fully recovered after the global financial crisis. Despite the instability of the economic system during the crisis, on the one hand, on the other hand, the US government carried out several important measures that gradually restored the pre-crisis indicators of economic development. Therefore, by 2019 , indicators that may affect the mortgage market mortgages showed a significant improvement. Thus, we can say that despite the global crisis, the US funding system is quickly returning to pre-crisis levels. This indicates that for the Russian practice of financing the construction of housing market objects, it is advisable to pay closer attention to the experience of the United States.

The aim of the study is to formulate recommendations on the adaptation of individual mechanisms in Russian practice based on an analysis of American experience in organizing financing for the construction of housing market objects. More attention will be paid to the mortgage market, as more in demand among the population as a source of financing housing acquisition.

To achieve this goal, it is supposed to solve the following tasks:

- analyze the experience of the United States;

- identify mechanisms that can be considered for use in Russia;

- formulate recommendations on the process of using foreign mechanisms in Russian practice.

Since mortgage lending is the most sought-after tool for financing home buying for American citizens, we will concentrate the study on it.

There are several studies on mortgage lending in the United States.

Park (2016), Moss (2017), Udland (2016), Boyd (2014), Reed and Wu (2010), Shim et al. (2013) in their works analyzed the housing and construction markets, including the American one, and also assessed the probability of a mortgage loan delay or non-payment depending on the use of insurance mechanisms [1-6].

Poorvu (2003) evaluated mortgage markets in terms of the models used, the mechanisms implemented [7]. In addition, mortgage models, their advantages and disadvantages were analyzed in their works by Scharfstein and Sunderam (2014), Pinkowish (2013), and Learning (2015) [8-10]. However, in these studies, the differences between the mechanisms and models of financing are presented largely, but no comprehensive proposals for the development of markets are given, considering the improvement of tools. Also, the authors do not assess the impact of the development of mortgage market instruments on the housing and construction market, and the economy. Moscone et al. (2014) analyze the housing market, it's financing and the risks associated with it [11]. 
Zhu et al. (2017) evaluate how monetary policy and the structure of the mortgage market influence the formation of prices for residential real estate in countries [12]. However, there is no coordination between monetary policy instruments and the mortgage market, which could improve the quality of market regulation. An assessment of the impact on the housing and construction market would also be significant. Basten and Koch (2015) interconnect housing prices and how they affect the supply and demand of mortgages [13]. Several authors assess the impact of mortgage lending on the availability of residential real estate [14].

Canepa (2016) shows in his study how the cyclical nature of the economy affects property prices [15].

Allen and Goetz analyze state funding for housing, including how modern politicians did not want to use it to provide affordable housing for migrants [16].

Berger et al. (2008) analyze the process of subsidizing the purchase of housing and to deal with social category such as single mothers [17]. Newman and Harkness (2002) deal with public housing finance and payback time [18].

Many studies on this topic suggests that it is a mortgage loan that is one of the main sources of financing for the construction of housing facilities used by American residents.

Sufficiently loyal lending conditions cause a reduction in the participation of homebuyers.

The Russian housing and construction market need a constant influx of funds to ensure the implementation of the housing plan and providing it to citizens of the country. Thus, attempts to introduce financing mechanisms that will achieve this are highly relevant.

Hypotheses:

- US housing and construction markets are leading in the global economy, using effective tools, one of which is a mortgage loan;

- there are financing problems in the US housing and construction market, as in many countries, but the process of restoring the assessment indicators of these markets is proceeding more rapidly than in other states;

- the development of financing instruments for the construction of housing market objects in Russia can be achieved by adapting individual elements from the experience of foreign countries, in the United States;

- when adapting the American experience in Russia, it is required to analyze the opportunities that have already been realized and try to take them into account when forming new tools for financing the construction of housing market facilities.

\section{Methods}

\subsection{Analysis of the subject composition of the housing and construction markets in the United States}

The analysis identified the need to analyze the subject composition of US housing markets and determine their role in financing the facilities of these markets. In addition, these entities regulate the credit rights of citizens and directly or indirectly participate in mortgage lending mechanisms. 


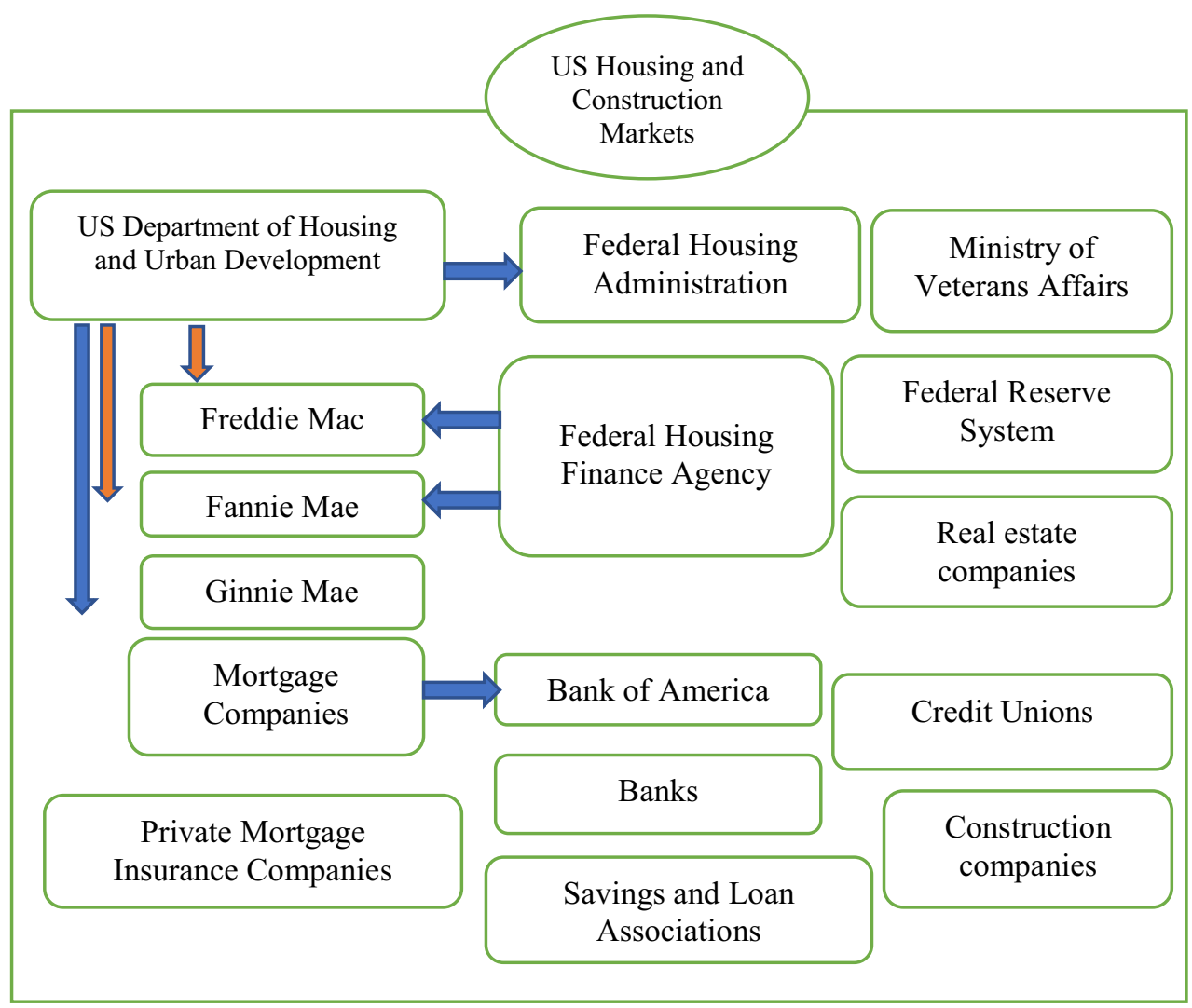

Fig. 1. The subject composition of the US housing and construction markets

Source: Author's development, considering: https://economics.studio/finansistam/obobscheniezarubejnogo-opyita-finansovogo-49470.html

The subject composition of the US housing and construction markets is quite extensive. This is primarily due to the long history of the development of markets, the formation of various mechanisms for financing these markets. This is due to mortgage funds and the need for operators who provide the whole process.

Consider the role of each of the entities in the housing and construction markets, and in the processes of financing them.

U.S. Department of Housing and Urban Development was officially established in 1966. The ministry is a federal executive body. The formation of the Ministry was based on the Law on Housing and Urban Planning. The main activities are the management of residential real estate construction and urban development programs. In addition, the Ministry should manage the implementation of the mission of Fannie Mae and Freddie Mac, regulate the activities of the fully state-owned corporation Ginnie Mae, etc.

Federal Housing Administration was established in 1934. The main tasks include improving housing conditions, creating an adequate system of financing the acquisition of residential real estate through mortgage insurance and stabilizing the mortgage market. The administration regulates mortgage rates and other loan conditions. Since 1966, the Housing Administration has become part of the Ministry of Housing and Urban Development.

In 2008, the Federal Housing Finance Agency was established through the functions of the Federal Housing Finance Council and the Federal Housing Oversight Office. The agency regulates the activities of Fannie Mae, Freddie Mac and 11 federal mortgage banks. 
The United States Department of Veterans Affairs is the executive body of the US government. The ministry was formed in 1930. In the framework of its activities, the body has the right to obtain mortgages, life insurance, assign pensions, allowances, benefits. One of the departments of the Ministry is the Veterans Benefits Administration. The administration provides housing and insurance benefits and allowances.

Fannie Mae is the largest mortgage agency. Created in 1938, it provides financing for more than $20 \%$ of the total volume of mortgage lending. The main segment of the mortgage market, which supports Fannie Mae, is the secondary market. The agency issues mortgagebacked securities, securing pools of mortgage loans and through this, the issuance of new loans is financed.

Freddie Mac, like Fannie Mae, is a major US mortgage agency. The agency was formed in 1970, financing mortgage loans. Despite being curated by the Department of Housing and Urban Development, Freddie Mac is a private company. Fannie Mae and Freddie Mac have been controlled by the Federal Housing Finance Agency since 2008. The government finances both organizations, that is, companies carry out activities to increase the influx of loans to target sectors, because of increasing their efficiency, transparency and reducing risks for potential investors. Ginnie Mae is the state national mortgage association. The organization was established in 1968. The function of Ginnie Mae is to expand funding opportunities to ensure affordable housing. The Association acts as a guarantor for investors to obtain the best price for loans in the capital market. Further, the funds received by investors can be used to provide new loans. Total financing costs are reduced. The mortgage association is not in itself a lender, does not issue mortgage-backed securities and does not carry out operations with them, but is a guarantor.

Mortgage companies are organizations whose activity is the creation and / or financing of mortgage loans for the purchase of residential or non-residential real estate. During the global financial crisis, a sufficiently large number of such companies went bankrupt, because they had little own funds. There are a number of mortgage companies offering a full range of services related to mortgage lending (forming a loan, servicing it, etc.). The differences between the companies are due to mechanisms of interaction with banks regarding loan financing, the list of offered banking products, underwriting standards, etc.

Currently, the largest US mortgage organizations are Wells Fargo (San Francisco), Bank of America Corporation, and Nation star Mortgage Holding. Wells Fargo is the largest US mortgage company. The volume of loans issued is $12.7 \%$ of the total mortgage lending. The company offers a wide range of services from issuing a loan and servicing it, to refinancing, etc. One of the common mechanisms is the provision of mortgages, the payments on which in the first years will be small compared with the subsequent ones. Most of the operations are carried out online without the need for personal presence in the company. However, if necessary, the organization can offer the client the services of a personal manager to simplify the procedure for working with credit.

Bank of America Corporation is a large financial organization that provides a wide range of services to both individuals and legal entities. The corporation credits and re-loans the purchase of housing. Compared with other financial institutions, the bank, when assessing the borrower's creditworthiness, can take into account not only its income, the availability of other real estate, but also the history of rental payments, the availability of a gym membership, etc. Moreover, the bank does not require compulsory mortgage insurance.

Nationstar mortgage holding is a non-bank mortgage company, which is one of the largest in the United States. The loan portfolio is more than 400 million dollars. USA. In addition to the general list of mortgage services, housing exchange services are also offered. In 2017, there was a rebranding and currently the company is called Mr. Cooper. A smaller share in financing the housing and construction markets is occupied by commercial 
banks, which also provide mortgage loans to borrowers. Loan and savings associations are financial institutions that accept citizens' savings, and upon reaching a certain amount specified in the contract (down payment, approximately $50 \%$ of the cost of housing), they additionally provide a mortgage loan at a lower rate for the full payment of residential real estate. At the same time, during the accumulation period, the citizen receives additional income in the form of interest on the deposit (usually the rates on these deposits are lower than the market ones). Credit unions are non-profit organizations operating in favor of their customers. With the accumulation of funds, members of the union receive a higher income on deposits, and if necessary, providing them a loan can get a lower rate. Private mortgage insurance companies carry out mortgage insurance, which more protects the lender from any risks. The borrower, who draws up a mortgage agreement on the best conditions, will be required to conclude an additional insurance contract. However, the contract may be terminated in advance if the amount of equity in repayment of the loan is at least $20 \%$.

The Federal Reserve System in the United States plays the role of a central bank, exercises centralized control over the banking system, protects the credit rights of customers, etc. Control over banks allows mortgage transactions to be made more transparent and effective. Construction companies accumulate public funds (including credit resources) and redirect them further to housing construction. Real estate companies can act as intermediaries between the owners of funds (borrowers) and construction companies or sellers of real estate (secondary market). Thus, the American subjective system of housing and construction markets has an extensive structure. Each subject covers a certain category of citizens or operation. Of course, the formation of such a system was achieved by not a single decade of development, having gone through both successful periods and periods of crisis.

\subsection{Assessment of the development of the US mortgage market}

Currently, despite the effects of the global financial crisis, a gradual increase in demand from citizens for mortgage lending has begun to be observed (Figure 2). Until 2019, we can talk about stable growth. The consequences of the current crisis associated with the epidemic may also affect the housing, construction and mortgage markets, but it is too early to make preliminary forecasts. We analyze the available data. Between 1990-2016, there was a steady growth. Even during the global financial crisis, the volume of mortgage lending decreased not so significantly. Peak values were noted in $2007 / 08$. Subsequently, a slight reduction in lending.

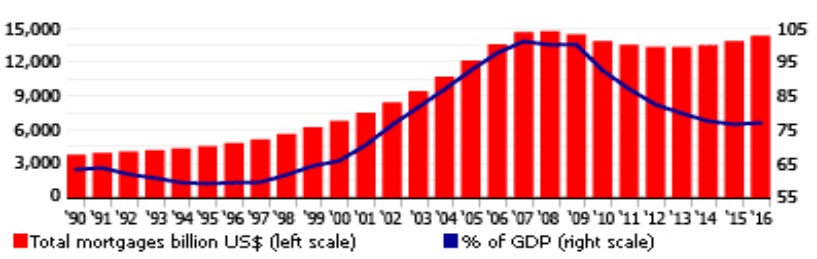

Fig. 2. The volume of mortgage lending in the United States, in billions of dollars. USA Source: US FED

Despite the relatively stable state of the indicator of the volume of mortgage lending, interest rates in 2017 began to grow. Therefore, the average level of the mortgage rate (fixed interest rate) over the past 30 years has grown in 2017 to $4.47 \%$. At the same time, in 2016 this indicator was at the level of $3.66 \%$. The floating mortgage rate rose to $3.2 \%$ in 2017 compared to $2.83 \%$ in 2016 . 


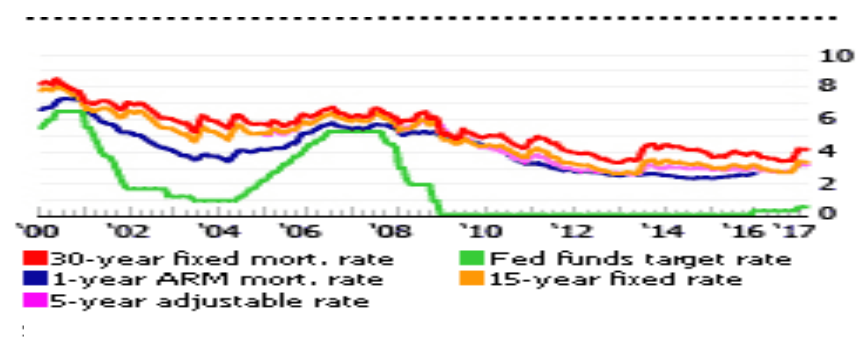

Fig. 3. Changes in mortgage rates in the US 2000-2017

Source: Freddie Mac Data, US Fed.

The growth in mortgage lending indicates an increase in home sales. The main reason investors buy residential real estate in the United States is mainly to generate income, considering the low-risk investment of temporarily available funds. Despite the problems that were observed during the global financial crisis, the United States maintained a leading position in the global economy according to several criteria. In the United States, there is a well-developed legislative framework in the field of regulation of housing, construction and mortgage markets, property rights and financing processes for these markets. Housing can be purchased with the help of mortgage loans, available on more loyal terms than, for example, in Russia or in many countries neighboring the United States. The main buyers of housing in the United States are investors in more than 70 countries. Most of them are from Mexico, Canada, India, and Great Britain. This contributes to an increase in mortgage lending. An important source of financing for the housing and construction markets is the Public Housing Capital Fund, which annually allocates Public Housing Agencies to help develop the industry. This allows you to increase the volume of construction, which ensures the satisfaction of demand for housing from the population. Let us analyze the latest results of the functioning of the housing, construction, and mortgage markets. The indicators were formed in a table based on the reporting of the company "Freddie Mac".

Table 1. Performance indicators for the housing, construction, and mortgage markets

\begin{tabular}{|c|c|c|c|}
\hline Indicator & 2017 & 2018 & 2019 \\
\hline Housing construction & 1.21 & 1.3 & 1.4 \\
\hline Total home sales & 6.17 & 6.35 & 6.45 \\
\hline $\begin{array}{l}\text { Estimation of the level of the } \\
\text { housing price index Freddie Mac, } \%\end{array}$ & 6.7 & 5.7 & 4.6 \\
\hline $\begin{array}{l}\text { Family mortgage: } \\
\text { - standard, } \$ \text {; } \\
\text { - mortgage of the Federal Housing }\end{array}$ & 1391 & 1339 & 1372 \\
\hline $\begin{array}{l}\text { Administration and the Ministry of } \\
\text { Veterans Affairs } \\
\text { Total. }\end{array}$ & 429 & 401 & 408 \\
\hline & 1820 & 1740 & 1780 \\
\hline Refinancing share, $\%$ & 36 & 25 & 23 \\
\hline Housing mortgage debt, $\%$ & 3.7 & 4.7 & 5.2 \\
\hline
\end{tabular}

Source: Freddie Mac company data

The data presented indicate that the availability of mortgage lending in the United States is quite high, which determines a further increase in lending over the long term. However, an increase in interest rates and housing prices in recent years has led to a slight decrease in accessibility. At the same time, an increase in demand for residential real estate by the population smooths out these changes. Soon a change in trend is possible. In general, it 
depends on the population belonging to the middle age group, which is the main buyer in the market.

In general, the analysis of statistical data indicates that mortgages have a sufficient level of accessibility and demand in the United States. Despite the global financial crisis, the volume of mortgages decreased slightly and by 2019 we can talk about an almost complete recovery of indicators. However, it is still difficult to assess how the situation will develop now. Will the new circumstances associated with the epidemic contribute to the desire of citizens to invest temporarily available funds in a relatively risk-free asset, or will a period of inhibition of market development begin.

\section{Results}

In the framework of this study, mortgage lending was chosen as one of the mechanisms for financing the construction of housing market facilities. After analyzing US statistics, it was found that despite the global financial crisis, recovery of pre-crisis indicators was observed quite quickly. This contributed to a stable growth in the construction of residential real estate, which is confirmed by the previously presented data in table 1 .

Based on the results of the analysis, we formulate the main loan conditions in the USA:

- loan term - 5-30 years. The most popular term is 15 and 30 years.

- interest rate - from 2.8-4.5\% per annum. In most cases, the rate is fixed, as it reduces the risks for borrowers. If the borrower chooses a floating interest rate, then it depends on the LIBOR rate.

- down payment - from $10-50 \%$. If borrowers participate in various programs, the down payment may be reduced.

- loan conditions for the purchase of housing do not depend on whether a purchase is made in the primary or secondary market.

- the presence of high competition among credit organizations significantly reduces the number of refusals to provide a mortgage loan.

- unlike many countries, in the United States, when calculating the amount of a loan provided, all sources of borrower's income (deposits, pension savings, rental payments from the delivery of personal real estate and other property, etc.) are taken into account.

- age of borrowers - from 25-75 years.

- a foreign citizen can get a mortgage, but on more stringent conditions than a US citizen (down payment of up to $30 \%$, interest rate of at least $10 \%$, a wide list of documentation).

- a foreign citizen can get a mortgage in the United States subject to a letter of trust from one of the largest US banks, where the deposit of a potential borrower is located. In this case, the contribution must be at least the amount of the down payment on the mortgage loan, transaction costs and additional reserve funds (at least the amount of the annual loan payment, home insurance, the cost of its assessment and total tax payments). You should also provide a letter of recommendation from a bank whose borrower is a resident of the country. It indicates the presence of a deposit for a period of at least two years and the amount of annual income with the application of its confirmation. The borrower provides a passport, a copy of the green card or a work visa, credit history, paid utility bills or another document that confirms the actual place of residence.

Next, we determine what can be used in the future in Russian practice to improve financing for the construction of housing market facilities and the functioning of the mortgage market. As for interest rates, they depend on the key rate of the Central Bank of 
the Russian Federation and gradually over the course of 2019, it gradually decreased. However, while Russian banks were not particularly willing to significantly reduce mortgage rates and so far, they remain at a high level in the region of $10 \%$ per annum. In the United States, it was precisely due to the reduction in rates that an increase in the volume of purchased housing was achieved, and hence financing of its construction. Largely, lending conditions in Russia differ depending on whether the object is located on the primary or secondary housing market. A possible unification of the rules could contribute to the growth of affordable lending. In Russian practice, you rarely see banks that consider rental payments as sources of funds. More inclined to official income. Besides this, it must be borne in mind that there is a problem of not providing citizens with information that they are renting any property. The USA's experience in providing the socalled international mortgage, that is, one that can be issued to a foreign citizen, is interesting. Despite the more stringent credit conditions than for US citizens over a long period, she had such a loan more attractive conditions than in Russian banks. That is, potentially, on the one hand, a foreigner could get a mortgage for the purchase of housing in the United States, and on the other, the acquisition of real estate in another country could be considered. This was not long practiced in Russia by individual small regional banks, but it was not widespread, and lending conditions could not be called attractive to the client. However, it is worth noting that this direction can be further developed in Russia and bring quite large profits to banks, since there is an annual increase in migration processes (especially from neighboring countries). Thus, we can say that there are some recommendations from the American experience that can be proposed for implementation in Russian practice.

\section{Discussion and Conclusion}

The analysis showed that the main housing finance tool in the US is a mortgage loan. The subject composition of the housing and construction markets is quite wide. Most of the entities represented are bodies that are directly involved in mortgage lending as the main activity. The subjects are closely interacting with each other, which allows you to quickly resolve issues with financing. The mortgage lending system for the entire modern period of development has moved from a mechanism with strict state regulation to a self-regulating economic system [20]. Important is the continued state support of this system, which is due to the need to solve the social problem of providing citizens with affordable housing. The US experience shows the positive results of the formation of a guarantee and insurance system. If insurance is to some extent present in Russia, then the situation with the guarantee system is much worse. In the United States, such a system has long been debugged. In Russian practice, it does not exist as such.

Thus, we can say that in the American experience, there are several areas that can be used in Russia - these are recommendations regarding mortgage lending and the introduction of a guarantee system.

\section{References}

1. Park, K. (2016). FHA loan performance and adverse selection in mortgage insurance. Journal of Housing Economics, 34, 82-97.

2. Moss, J. (2017). The similarities and differences between the US housing market in 2017. Internationalbanker. Retrieved from: internationalbanker.com. 
3. Udland, M. (2016, March 7). The US housing market has a major supply problem. Retrieved from: https://www.businessinsider.com/housing-market-supply-problem2016-3

4. Boyd, T. (2014). Property market analysis. The key to looking forward. PRRES. Retrieved from: http://www.prres.net/papers/Boyd_Property_Market_Analysis.pdf.

5. Reed, R., Wu, H. (2010). Understanding property cycles in a residential market. Property management, 28(1), 33-46.

6. Shim, I., Bogdanova, B., Shek J., Subelyte, A. (2013). Database for policy actions on housing markets. Retrieved from: http://www.bis.org/publ/qtrpdf/r_qt1309i.pdf.

7. Poorvu, W.J. (2003). Financial analysis of real property investments. Harvard Business School.

8. Scharfstein, D., Sunderam, A. (2014). Market power in Mortgage Lending and the Transmission of Monetary Policy. Harvard University and NBER.

9. Pinkowish, T.J. (2013). Residential Mortgage Lending: Principles and Practices. Cengage Learning.

10. Learning, H. (2015). Mortgage Lending Principles and Practices. Hondros Learning.

11. Moscone, F., Tosetti, E., Canepa, A. (2014). Real estate market and financial stability in US metropolitan areas: A dynamic model with spatial effects. Regional Science and Urban Economics, 6 (50), 1-23.

12. Zhu, B., Betzinger, M., Sebastian S. (2017). Housing market stability, mortgage markets structure, and monetary policy: Evidence from the euro area. Journal of Housing Economics, 37, 1-21.

13. Basten, C., Koch, C. (2015). The causal effect of house prices on mortgage demand and mortgage supply: Evidence from Switzerland. Journal of Housing Economics, 30, $1-22$.

14. McCord, M., McGreal, S., Berry, J., Haran, M., Davis, P. (2011). The implications of mortgage finance on housing market affordability. International Journal of Housing markets and analysis, 4(4), 394-417.

15. Canepa, A, Chini, E. Z. (2016). Dynamic asymmetries in house price cycles: A generalized smooth transition model. Journal of Empirical Finance, 37, 91-103.

16. Allen, R., Goetz, E.G. (2020, August 11). A home for xenophobia: U.S. public housing policy under Trump. International Journal of Housing Policy. Retrieved from: https://doi.org/10.1080/19491247.2020.1803533.

17. Berger, L.M., Heintze, T., Naidich, W.B., Meyers, M.K. (2008). Subsidized housing and household hardship among low-income single-mother households. Journal of Marriage and Family, 70(4), 934-949.

18. Newman, S. J., Harkness, J. M. (2002). The long-term effects of public housing on self-sufficiency. Journal of Policy Analysis and Management, 21(1), 21-43.

19. Bondinuba, B., Stephens, M., Jones, C., Buckley R. (2020). The motivations of microfinance institutions to enter the housing market in a developing country, International Journal of Housing Policy, 20(4), 534-554.

20. Dementiev, N.P. (2012). The current state of mortgages in Russia and the USA. Industrial Development of Russia. Institute of Economics and Industrial Engineering SB RAS. 